\title{
STUDI TERHADAP FAKTOR-FAKTOR YANG MENENTUKAN KINERJA SEORANG KARYAWAN
}

\author{
Ramadhi ${ }^{1}$, Andi Amri ${ }^{2}$, Zulmi Ramdani ${ }^{3}$ \\ ${ }^{1}$ Manajemen, Fakultas Ekonomi, Universitas Andalas \\ ${ }^{2}$ Manajemen, Fakultas Ekonomi dan Bisnis, Universitas Pancasila \\ ${ }^{3}$ Psikologi, Fakultas Psikologi, UIN Sunan Gunung Djati Bandung \\ 1ramadhi94@yahoo.com, ${ }^{2}$ andiamri43@gmail.com,${ }^{3}$ zulmiramdani@uinsgd.ac.id
}

\begin{abstract}
Aim of study is to see the role of, job stress, work environment, and job satisfaction on work performance at Arita Prima Indonesia Company in West Sumatra province. Quantitative research design is used to answer these objectives. The study used multiple linear regression and questionnaires as data collection methods which were filled out by employees of Arita Prima Indonesia Company, Branch of West Sumatra province. The result show there are 4 information, namely: 1) the work environment has a positive role on worker performance, 2) job stress has a negative role on worker performance, 3) job satisfaction has a significant and positive role on worker performance, and 4) Simultaneously, the three independent variables tested played a role on worker performance. Meanwhile, seen from the contribution of the three independent variables of $72.8 \%$ and the other are determined by other untested situations.
\end{abstract}

Keywords: Employee Performance, Work Environment, Work Stress, Job Satisfaction.

\begin{abstract}
Abstrak: Studi ini ingin melihat peran dari stress pekerjaan, lingkungan tempat kerja, serta kepuasan pekerjaan terhadap performa seorang karyawan pada perusahaan Arita Prima Indonesia, cabang provinsi Sumatera Barat. Desain penelitian kuantitatif digunakan untuk menjawab tujuan tersebut. Regresi linear berganda dilakukan dalam studi ini dan kuesioner sebagai metode pengumpulan data yang diisi oleh karyawan PT. Arita Prima Indonesia, Tbk cabang provinsi Sumatera Barat. Berdasarkan hasil penelitian menunjukkan ada 4 temuan, yaitu: 1) lingkungan tempat kerja berperan positif dalam membentu kinerja seorang karyawan, 2) stres kerja berperan negatif pada kinerja seorang karyawan, 3) kepuasan pekerjaan berperan signifikan dan positif terhadap kinerja seorang karyawan, dan 4) Secara simultan, ketiga variabel independen yang diujikan berperan signifikan terhadap kinerja karyawan. Sementara dilihat dari kontribusi variabel yang ada yaitu sebesar $72.8 \%$, dan sisanya ditentukan oleh situasi lainnya yang tidak diuji.
\end{abstract}

Kata Kunci : Lingkungan Kerja, Kepuasan Kerja, Stres Kerja, Kinerja Karyawan

\section{PENDAHULUAN}

Ilmu ekonomi menjelaskan bahwa suatu perusahaan berusaha mencapai keberhasilan dengan memanfaatkan peluang yang terjadi dilingkungan bisnis. Hal ini dilakukan oleh seorang pebisnis handal dengan melihat, menganalisa, dan melakukan pilihan terhadap berbagai peluang, demi kemajuan bisnisnya (Amri, 2020). Salah satunya dapat dilakukan dengan melihat potensi individu yang ada didalamnya, sehingga keberhasilan yang diharapkan perusahaan dapat tercapai. Kinerja karyawan tentu saja berkaitan langsung dengan produktivitas dan keuntungan perusahaan karena hal ini sepenuhnya merupakan hasil kerja, proses dan dinamika di dalam perusahaan (Amri \& Ramdani, 2021). Menurut Rivai (2015) bahwa sumber daya manusia adalah suatu unsur masukan (input) yang mana nantinya akan berubah menjadi keluaran (output) bertujuan untuk mencapai ekspektasi yang ditentukan oleh suatu organisasi. 
Untuk memperoleh tujuan yang diharapkan perusahaan tentunya ada beberapa kendala atau pemasalahan yang terjadi dimana permasalahan ini terjadi karena kurang optimalnya kinerja karyawan. Sedarmayanti (2017) menjelaskan kinerja karyawan ialah suatu hasil yang didapatkan individua tau kumpulan individu didasarkan pada tugas dan tanggungjawab masing-masing yang didasarkan kepada penilaian yang diberikan. Penilaian karyawan dilakukan dengan mempertimbangkan suatu kondisi yang dapat mempengaruhi kinerja karyawan. Setiap perusahaan tentunya sangat mengharapkan karyawan yang memiliki prestasi sebab dengan berprestasinya karyawan akan dapat memberikan kemajuan terhadap perusahaan.

Karyawan yang memiliki prestasi tentunya dapat meningkatkan kinerja perusahaan. Kinerja perusahaan juga akan meningkat apabila perusahaan memperhatikan stres kerja karyawannya (Arshadi \& Damiri, 2013; Yozgat dkk., 2013). Stres merupakan kondisi seseorang mengalamin suatu tegangan yang disebabkan karena kondisi mental yang berasal dari lingkungan dalam maupun dari eksternal individu. Stres akan menghasilkan pengaruh yang negatif bagi perusahaan hal ini dikarenakan suatu keadaan psikologis maupun biologis. Stres yang dialami tentunya tidak berasal dari penyakit fisik tetapi lebih mengenai jiwa karyawan (Jauvani, 2013). Stres yang tinggi akan mengancam kemampuan seseorang dalam lingkungannya. Hasil dari stres yang tinggi akan mengakibatkan pelaksaan kerja akan terganggu dan juga dapat menganggu kinerja karyawan. Karyawan yang mengalami stres biasanya menjadi pribadi yang tertekan dan merasakan kekhawatiranpada dirinya. Karyawan akan berprilaku tidak koorperatif, tidak rileks, mudah marah, dan tentunya sangat agresif. Sumber stres yang dialami karyawan ini berasal dari tuntunan tugas, tuntunan peran dan tuntunan pribasdi. Untuk mengoptimalkan kinerja masing-masing karyawan tentunya perusahaan harus dapat mengindari stres yang terjadi pada karyawan.

Stres kerja juga dapat merusak kepuasan kerja karyawan. Menurut Marchelia (2014), kepuasan kerja mengacu pada suatu kondisi yang memuaskan dan maksimal dalam diri pegawai pada hasil penilaian pekerjaan yang dilakukannya. Semakin tingginya penilaian terhadap perusahaan maka yang dirasakan karyawan, sesuai dengan keinginan karyawan maka akan semakin semakin puas seseorang dalam pekerjaannya. Agar karyawan komitmen terhadap pekerjaannya setidaknya perusahaan lebih memperhatikan kepuasan kerja karyawan serta lingkungan kerjanya, karena dalam melaksanakan tugas tentunya karyawan membutuhkan lingungakn kerja yang kondusif seperti memberikan sarana dan prasaran serta suasana ditempat kerja sehingga karyawan optimal dalam bekerja. Nabawi (2020) menyatakan bahwa lingkungan kerja merupakan kondisi dimana perusahaan memberikan sarana dan prasaran yang dibutuhkan oleh karyawan dalam meniti pekerjaannya serta melihat suasana atau memperhatikan suasana ditempat kerja. Peningkatan akan kinerja karyawan ini juga harus diiringi dengan meningkatkan lingkungan kerjanya dalam hal menciptakan kebersihan, keamanan dan menjauhkan dari rasa kebisingan. Selain itu, memperhatikan lingkungan kerja hal ini dapat mendorong kenyamanan karyawan dalam bekerja sehingga yang menjadi cita-cita dan tujuan perusahan akan sama-sama tercapai dalam hal peningkatan kinerja karyawan. 
PT. Arita Prima Indonesia, Tbk cabang Sumatera Barat termasuk ke dalam perusahaan besar yang mengurusi terkait kondisi valves di Padang. Pada dasarnya perusahaan tersebut merupakan perusahaan yang memiliki visi dan target untuk meraih suatu target pada penjualannya, perusahan yang mempunyai kedisiplinan terhadap peraturan perusahaan, dan melayani para cosumernya dengan baik. Selain itu, perusahaan ini juga terus menerus mempertahankan brand image dengan kebijakan-kebijakan terbaik dalam promosi maupun strategi pemasaran serta distribusi yang optimal.

Masalah yang dihadapi PT. Arita Prima Indonesia, Tbk cabang Sumatera Barat yang bergerak dibidang valves yaitu penilaian kinerja karyawan masih jauh dari kategori baik. Seperti yang terlihat pada tabel 1 tentang performa karyawan PT. Arita Prima Indonesia, Tbk cabang Sumatera Barat.

Tabel 1. Deskripsi Kinerja Karyawan Arita Prima Indonesia

\begin{tabular}{|c|l|c|c|}
\hline No & \multicolumn{1}{|c|}{ Faktor } & Nilai & Kriteria \\
\hline 1 & Kedisiplinan ketepatan masuk jam kerja & 66,8 & Baik \\
\hline 2 & Kedisiplinan kehadiran & 50,6 & Kurang \\
\hline 3 & Teliti dan tepat waktu & 90,6 & Sangat Baik \\
\hline 4 & $\begin{array}{l}\text { Kedisiplinan ketepatan } \\
\text { pekerjaan }\end{array}$ & 71,3 & Baik \\
\hline 5 & Kedisiplinan penyelesaian tugas & 70,0 & Baik \\
\hline 6 & Pengembangan karir & 50,8 & Kurang \\
\hline 7 & Manfaat pelatihan & 77,2 & Baik \\
\hline 8 & Fasilitas kerja & 70,0 & Baik \\
\hline 9 & Suasan Kerja & 66,7 & Baik \\
\hline 10 & Ketepatan menyelesaikan tugas & 69,8 & Baik \\
\hline 11 & Motivasi dalam kerja & 54,2 & Kurang \\
\hline 12 & Wawasan kerja & 70,1 & Baik \\
\hline 13 & Faktor pengaruh gaji & 55,9 & Kurang \\
\hline 14 & Peningkatan prestasi & 54,3 & Kurang \\
\hline 15 & Motivasi gaji & 56,7 & Kurang \\
\hline
\end{tabular}

Sumber: PT. Arita Prima Indonesia, Tbk Cabang Sumatera Barat, 2015

Dari tabel 1, diketahui bahwa setiap aspek kinerja karyawan memiliki nilai yang berbeda-beda yaitu; kedisiplinan ketepatan masuk jam kerja memiliki nilai 66,8\% (Baik), kedisiplinan kehadiran memiliki nilai 50,6\% (Kurang), kedisiplinan kmemiliki nilai 90,6\% (Sangat Baik), kedisiplinan ketepatan penyelesaian pekerjaan memiliki nilai 71,3\% (Baik), fasilitas kerja memiliki nilai 70,0\% (Baik), suasana kerja memiliki nilai 50,8\% (Kurang), ketepatan menyelesaikan tugas memiliki nilai 70,2\% (Baik), motivasi dalam kerja memiliki nilai 54,2\% (Kurang), wawasan kerja memiliki nilai 70,1\% (Baik), faktor pengaruh gaji memiliki nilai 55,9\% (Kurang), peningkatan prestasi memiliki nilai 54,3\% (Kurang), motivasi gaji memiliki nilai 56,7\% (Kurang). Terlihat PT. Arita Prima Indonesia, Tbk, cabang Sumatera Barat memiliki penilaian kinerja karyawan rata-rata sudah memiliki penilaian yang cukup baik, namun ada 6 aitem yang masih sangat jelek dalam segi kehadiran, pengembangan karir, motivasi karyawan, gaji yang diterima, prestasi 
kerja dan motivasi gaji. Sehingga 6 aitem ini sangat mempengaruhi kinerja dari perusahaan ini. Tentu seorang atasan melihat penilaian seperti ini akan merasa tidak puas, sementara dari segi peneliti ini perlu diteliti dan dicari solusi kenapa bisa terjadi. Selanjutnya, kita juga dapat melihat kinerja karyawan dari sisi absensi karyawan. Sementara itu, tabel 2 menjelaskan bagaimana kondisi kehadiran karyawan.

Tabel 2 Absensi karyawan di Arita Prima Indonesia Selama tahun 2014-2018 dengan Hari Kerja: 23 hari

\begin{tabular}{|c|c|c|c|}
\hline Tahun & $\begin{array}{c}\text { Jumlah } \\
\text { Karyawan } \\
\text { (Orang) }\end{array}$ & $\begin{array}{c}\text { Absensi } \\
\text { Karyawan }\end{array}$ & $\begin{array}{c}\text { Tingkat Ketidak } \\
\text { hadiran } \\
\text { Karyawan (\%) }\end{array}$ \\
\hline 2014 & 30 & 20,50 & 79,50 \\
\hline 2015 & 30 & 20,40 & 79,60 \\
\hline 2016 & 30 & 20,13 & 79,87 \\
\hline 2017 & 30 & 20,13 & 79,87 \\
\hline 2018 & 30 & 19,60 & 80,40 \\
\hline
\end{tabular}

Sumber: PT Arita Prima Indonesia Tbk Cabang Sumatera Barat

Dari tabel 2 diatas dapat dilihat tingkat kehadiran karyawan PT. Arita Prima Indonesia, Tbk cabang Sumatera Barat sejak tahun 2014 sampai pada tahun 2015 mengalami peningkataan. Pada tahun 2014 tingkat kehadiran karyawan 79,50\%, tahun 2015 tingkat kehadiran karyawan 79,60\%, tahun 2016 tingkat kehadiran karyawan 79,87\%, tahun 2017 tingkat kehadiran 79,87\%, tahun 2018 tingkat kehadiran 80,40\%. Tingginya tingkat kehadiran karyawan merupakan salah satu indikasi umumnya stres kerja dan kepuasan kerja karyawan. Terdapat banyak faktor penyebab absensi, dan pada umumnya bervariasi. Tapi penulis melihat bahwa kecenderungan ketidakpuasan karyawan terhadap perusahaan yang menyebabkan terjadinya penurunan kinerja karyawan PT. Arita Prima Indonesia Tbk cabang Sumatera Barat.

Berdasarkan kedua tabel diatas, penulis dapat menyimpulkan bahwa aspek kinerja karyawan masih belum tercapai, dilihat dari penilaian kinerja karyawan sebagian besar berada pada kategori kurang optimal. Kurang optimalnya kinerja karyawan disebabkan oleh faktor-faktor meliputi keadaan stres dalam kerja, situasi kepuasan kerja serta situasi lingkungan tempat kerja karyawan. Stres kerja berada pada dimensi yang negatif, sehingga secara linier ketika seseorang berada pada kondisi tersebut maka akan menghasilkan performa yang tidak maksimal (Wang dkk., 2020). Berbeda dengan dua faktor lainnya yaitu kepuasan pekerjaan serta lingkungan pekerjaan. Kepuasan pekerjaan dan lingkungan tempat kerja memiliki dimensi yang positif dan linier dengan performa, ketika keduanya berada pada kondisi optimal maka akan menghasilkan performa yang semakin baik. Namun, secara teoretis dan praktis ketiga faktor yaitu stres karena kerja, lalu lingkungan tempat kerja dan kepuasaan kerja berperan optimal terhadap performa kerja karyawan.

Lingkungan tempat kerja meliputi berbagai kondisi dalam pekerjaan yang mungkin muncul dari berbagai faktor di sekeliling seorang karyawan. Bisa berupa lingkungan fisik dimana karyawan bekerja, hubungan sosial dan interpersonal karyawan dengan pihak lainnya, sampai pada iklim dalam perusahaan yang digelutinya. Sementara itu, kepuasaan kerja bisa diperoleh ketika seseorang karyawan bisa mendapatkan hak-haknya dengan 
sesuai, terjadi pemenuhan kebutuhan secara fisik dan psikologis serta bisa berkembang lebih produktif. Atas dasar itulah, lingkungan kerja dan kepuasaan kerja seorang karyawan dianggap berpengaruh juga terhadap performa kerja seorang karyawan (Arshadi \& Damiri, 2013; Arshadia, 2010; Monroe dkk., 2020; Viotti dkk., 2020).

Penelitian terdahulu kemudian menguatkan tentang studi yang dilakukan penulis pada penelitian ini, seperti Julvia (2016) dan Sari dkk. (2012) kemudian menjelaskan tentang keadaan stres kerja berdampak terhadap kinerja karyawan, sementara pendapat tersebut dibantah oleh Mahardiani dan Pradhanawati (2013) dan Sandiartha dan Suwandana (2020) yang menyebutkan bahwa stres pekerjaan tidak berperan dengan signifikan dalam mempengaruhi kinerja seorang karyawan. Sedangkan untuk kepuasan kerja, Indrawati (2013) dan Saputra dan Bagia (2016) menyatakan memiliki peran yang signifikan. Hal berbeda yang diungkapkan oleh Changgriawan (2017) menyatakan kepuasan pekerjaan tidak menjadi sebuah peran signifikan terhadap performa seorang karyawan. Terakhir lingkungan tempat kerja, menyatakan ada pengaruh terhadap kinerja karyawan adalah penelitian dari Rahmawanti (2014).

Sangat banyak penelitian sejenis terkait dengan variabel ini dan hasilnya pun beragam, namun keunggulan dari penelitian adalah menggunakan objek perusahaan yang berbeda dan pastinya penelitian dilakukan didaerah Sumatera Barat. Sehingga tentunya akan memiliki kebermanfaat untuk perusahaan kedepannya. Tujuan dari penelitian ingin melihat peran lingkungan tempat kerja, stres di tempat kerja, serta kepuasan pekerjaan melalui skema parsial terhadap pada kinerja seorang karyawan dan juga mengetahui seberapa besar peran lingkungan tempat kerja, stres pekerjaan, dan kepuasan kerja melalui skema simultan atau menyatu bersama. Oleh karena itu, penulis tertarik untuk melihat peran lingkungan kerja, stres di tempat kerja, dan kepuasan pekerjaan terhadap performa karyawan PT. Arita Prima Indonesia Cabang Sumatera Barat.

\section{LANDASAN TEORI DAN PENGEMBANGAN HIPOTESIS Kinerja Karyawan}

Prawirosentono (2014), menjelaskan tentang kinerja atau performa sebagai sesuatu yang harus digapai oleh individu untuk mencapai keberhasilan atas pekerjaan yang diberikan kepadannya sesuai dengan tujuan perusahaan. Dalam kinerja perusahaan harus dilakukan penilaian kinerja. Penilaian kinerja bertujuan untuk menciptakan kedisiplinan karyawan terhadap peraturan dalam perusahaan, menciptakan karyawan yang kreativitas untuk menyelesaikan pekerjaan dikantor, pertanggungjawaban sebagai standar untuk keptusan gaji, promosi dan kenaikan jabatan, dan terakhir pengembangan dalam kapasitas kemampuan seorang karyawan dalam bentuk pelatihan, bimbingan dan bantuan (Wartono, 2017).

\section{Stres Kerja}

Menurut (Purwato, 2017) Stres kerja dapat diartikan sebagai salah kondisi yang dapat mempengaruhi emosi seseorang yang disebabkan karena adanta tegangan dalam kondisi kerja. Stres yang berlebihan dapat menganggu kemampuan seseorang dalam mengahadapi lingkungannya, yang nantinya akan menghasilkan kinerja yang tidak optimal 
dalam pelaksanaan kerja pada perusahaan ataupun organisasi. Karyawan yang mengalami stres yang berlebih biasanya akan merasa nerveous atau kekhawatiran yang terjadi pada dirinya selain itu juga akan mengalami penyakit fisik seperti tekanan darah tinggi dan sulit tidur (Prasetyo, 2019).

\section{Kepuasan Kerja}

Wibowo, (2017) mengartikan kepuasan pekerjaan merupakan sikap yang umum pada seseorang yang dijadikan sebagai pembeda antara apa yang diterima dengan diyakininya. Seseorang tentunya memiliki kepuasan yang berbeda terhadap pekerjaannya. Semakin tingginya kepuasan yang dimiliki seseorang tentunya akan dapat mendorong perusahaan untuk dapat mencapai tujuannya, sedangkan kepuasan yang rendah tentunya akan dapat mengancam perusahaan mengalami permasalahan seperti kerugian ataupun keumunduran perusahaan untuk berjalan (Priansa, 2016).

\section{Lingkungan Kerja}

Afandi (2018) menyatakan bahwa segala sesuatu yang berada dalam lingkungan pekerja akan menentukan adaptabilitas diri untuk beraktivitas pada hal-hal yang akan dijalankan. Lingkungan pekerjaan dengan kondisi yang memadai dapat member rasa nyaman dan aman sehingga para pekerja bersemangat dalam bekerja. Lingkungan kerja juga dapat mempengaruhi tingkat emosional seseorang yang dikarenakan suasana kerja yang kurang nyaman. Lingkungan kerja tidak hanya alat perkakas saja namun juga suasana kerja pa lingkungan perusahaan (Danang, 2015).

\section{Kerangka Berpikir}

Berdasarkan rumusan masalah dalam penelitian ini dapat ditarik simpulan bahwa pengaruh stres pekerjaan, kepuasan kerja, dan lingkungan memiliki peran yang signifikan terhadap kinerja seorang karyawan dilihat dari struktur parsial ataupun simultan, sehingga didapatkan kerangka pemikiran yang bisa dilihat pada gambar 2 .

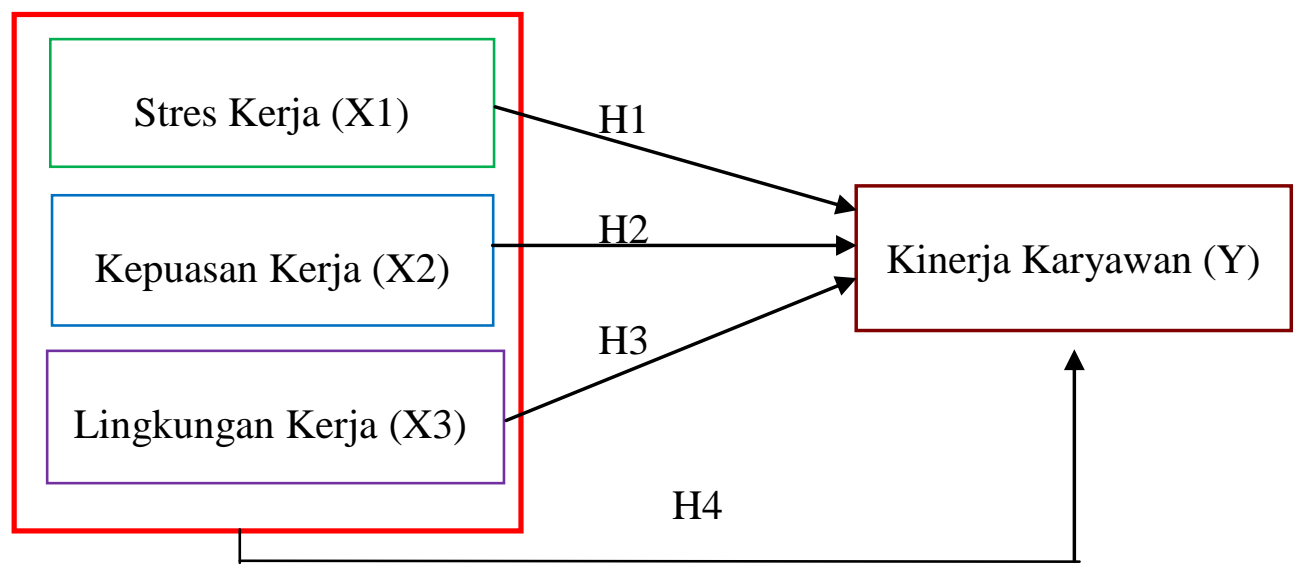

Gambar 2. Kerangka Berpikir Penelitian 


\section{Hipotesis}

Beberapa hipotesis yang diajukan oleh peneliti diantaranya adalah:

\section{Peran Stres Kerja terhadap Kinerja Karyawan}

Banyak teori yang menjelaskan bahwa ketika seseorang mengalami stres kerja hal ini akan berdampak negatif bagi keberlangsungan personal dan lingkungan pekerjannya. Dharmayasa dan Adnyani (2020) menyatakan bahwa stres kerja yang tinggi akan mengakibatkan kinerja karyawan maupun perusahaan menjadi kurang optimal. Stres kerja juga akan dapat menghamat karir seseorang dalam perusahaan. Stres kerja yang tinggi akan menyebabkan emosional seseorang menjadi tidak dapat dikontrol dengan baik sehingga menyebabkan suatu ketegangan dalam dirinya.

\section{H1: Stres Kerja berperan negatif terhadap Kinerja Seorang Karyawan}

\section{Peran Kepuasan Pekerjaan terhadap Kinerja Karyawan}

Secara teori bahwa kepuasan kerja berdampak positif bagi kinerja seorang karyawan diaman dengan adanya penghargaan yang diberikan kepada karyawan. Jika penghargaan yang diberikan seseuai dengan prestasi karyawan maka ia akan merasakan kepuasaan yang begitu besar dalam dirinya begitu pula sebaliknya ketika individu merasa tidak puas akan memunculkan suatu perasaan frustasi dalam pekerjaannya. (Nuryanti, 2020) menyatakan bahwa semakin puasnya seseorang terhadap pekerjaannya akan menyakibatkan semakin tingginya kinerja seseorang tersebut., begitupun sebaliknya jika seseorang merasakan ketidakpuasan dalam pekerjaannya akan akan menyebabkan penurunan pada kinerjanya dan tujuan perusahaan tidak akan tercapai.

H2: Kepuasan Kerja berperan signifikan dan positif terhadap Kinerja Karyawan

\section{Peran Lingkungan Kerja Terhadap Kinerja seorang Karyawan}

Lingkungan kerja adalah suatu keadaan yang dapat berpengaruh terhadap performa karyawan, dimana ketika lingkungan kerja seorang karyawan nyaman maka tentunya akan mempertinggi kinerja oleh karyawan. Semakin baiknya lingkungan kerja pada suatu perusahaan maka akan mengakibatkan sekain tingginya kinerja karyawan hal ini disebabkan karena karyawan merasa nyaman dan aman pada lingkungannya. Lingkungan kerja yang nyaman merupakan lingkungan dimana pimpinan memberikan suasana yang baik, fasilitas yang baik dan lainnya sehingga akan dapat membawa dampak psitif bagi karyawan terhadap perusahaan (Yuliantari \& Prasasti, 2020).

H3: Variabel Lingkungan kerja berperan positif dan signifikan terhadap Kinerja Karyawan 


\section{Peran Stres kerja, Kepuasan Kerja dan Lingkungan terhadap Kinerja Karyawan}

Dalam rangka mengoptimalkan kinerja seorang karyawan di dalam suatu perusahaan harus bisa mengatur stres kerja seorang karyawan, memperhatikan kepuasan kerja seorang karyawan serta melihat lingkungan kerja karyawan sehingga nantinya akan terbentuk kinerja yang optimal dan juga dapat meningkatkan produktivitas perusahaan, karena menjadi seorang karyawan adalah modal berharga yang harus selalu dipertimbangkan oleh banyak perusahaan.

H4: Stres kerja, Kepuasan Kerja dan Lingkungan tempat kerja secara simultan berperan signifikan terhadap Kinerja seorang Karyawan

\section{METODE PENELITIAN}

Peneliti menggunakan desain kuantitatif dengan jenis survei untuk menjawab hipotesis yang diajukan (Sugiyono, 2017).

\section{Populasi dan Sampel}

\section{Populasi}

Menurut Suharsimi (2010), istilah populasi meruapkan area generalisasi yang didasarkan pada karakteristik tertentu. Populasi penelitian ini merupakan keseluruhan karyawan pada PT. Arita Prima Indonesia dengan jumlah responden banyak 30 orang.

\section{Sampel}

Sampel merupakan uraian dari populasi (Sugiyono, 2017). Dalam memilih responden digunakan metode sensus untuk memperoleh gambaran suatu sampel dari sebuah populasi yang ditentukan. Yang menjadi sampel di dalam penelitian ini merupakan selutuh karyawan pada PT. Arita Prima Indonesia, Tbk berjumlah 30 orang karyawan.

\section{Instrumen Penelitian}

Instrumen yang dikembangkan dalam penelitian menggunakan model penskalaan likert. Menurut Sugiyono (2017) yang menjelaskan skala likert sebagai skala yang dapat diukur melalui instrumen pernyataan dalam penelitian. Skala likert ini terdiri dari lima skala, (1 untuk jawaban sangat tidak setuju sampai dengan skor lima yang menggambarkan situasi sangat setuju).

Tabel 4 Rancangan (Blue Print) Instrumen Alat Ukur

\begin{tabular}{|l|c|c|c|c|}
\hline No & Sub Variabel & Indikator & $\begin{array}{c}\text { Item } \\
\text { Pertanyaan }\end{array}$ & No. Item \\
\hline 1 & Stres Kerja & 1. Jumlahnya tugas yang & 4 & $1,2,3,4$ \\
& & ada & 3 & $5,6,7$ \\
& & 2. $\begin{array}{l}\text { Tekanan terhadap peran } \\
\text { seorang pekerja }\end{array}$ & 3 & $8,9,10$ \\
& & 3. Dinamika personal & & \\
& & karyawan & & \\
\hline 2 & Kepuasan Kerja & 1. Psikologi & 3 & $1,2,3$ \\
& & 2. Sosial & 4 & $4,5,6,7$ \\
& & 3. Fisik & 2 & 8,9 \\
\hline
\end{tabular}




\begin{tabular}{|l|l|l|c|c|}
\hline & & 4. Finansial & 1 & 10 \\
\hline 3. & Lingkungan kerja & 1. Warna yang ada & 1 & 1 \\
& & 2. Kebersihan lingkungan & 2 & 2.3 \\
& & 2 & 3,4 \\
& 3. Sirkulasi udara & 2 & 5,6 \\
& 4. Level penerangan & 1 & 7 \\
& 5. Tingkat kebisingan & 2 & 8,9 \\
& 6. Level keamanan & 1 & 10 \\
\hline
\end{tabular}

\section{Uji Hipotesis}

\section{Analisis Data}

Analisis melalui regresi linear yang berganda dilakukan dimana berguna untuk untuk melihat peran stres karena kerja, kepuasan pekerjaan dan lingkungan kerja terhadap kinerja karyawan PT. Arita Prima Indonesia, Tbk Cabang Sumatera Barat. Peneliti menggunakan bantuan dari software SPSS untuk melakukan analisis yang ada.

\section{HASIL PENELITIAN DAN DISKUSI}

\section{Analisis dengan Regresi Berganda}

Analisis ini dilakukan untuk melihat besaran peran dari Stres Kerja (X1), Kepuasan Kerja (X2) dan Lingkungan Kerja (X3) berperan terhadap Kinerja Karyawan PT. Arita Prima Indonesia, Tbk Cabang Sumatera Barat (Y)(lihat pada tabel 5).

\section{Tabel 5 Analisis dengan Regresi berganda}

\begin{tabular}{|c|c|c|c|c|c|c|}
\hline \multicolumn{2}{|c|}{ Model } & \multicolumn{2}{|c|}{ Koefisien Unstandar } & \multirow{2}{*}{$\frac{\text { Koefisien Standar }}{\text { Beta }}$} & \multirow[t]{2}{*}{$\mathrm{t}$} & \multirow[t]{2}{*}{ Sig. } \\
\hline & & $\mathrm{B}$ & Std. Error & & & \\
\hline \multirow{4}{*}{1} & Nilai Konstanta & 16,019 & 3,145 & & 5,094 &, 000 \\
\hline & Stres.Kerja &,- 261 & , 144 &,- 323 & $-1,815$ & ,081 \\
\hline & Kepuasan.Kerja & ,460 &, 113 &, 577 & 4,078 & ,000 \\
\hline & Lingkungan.Kerja & ,493 & ,112 & ,674 & 4,387 & 000 \\
\hline
\end{tabular}

a. Dependent Variable: Kinerja.Karyawan

Penjelasan mengenai analisis regresi linear berganda dapat diinterpretasikan:

1. Konstant sebesar 16,019 dapat diartikan apabila Stres karena Kerja, Kepuasan Kerja dan Lingkungan Kerja tidak muncul sehingga mengakibatkan performa Karyawan tetap sebesar konstanta 16,019.

2. Stres kerja memiliki koefisien negatif sebesar -0,261 yang mana ini menunjukkan sesungguhnya level stres karena pekerjaan ditingkatkan satu satuan maka akan menyebabkan penurunan Kinerja Karyawan sebesar 0,261.

3. Kepuasan kerja memiliki koefisien positif sebesar 460 yang mana ini berari bahwa jika kepuasan kerja ditingkatkan satu satuan maka akan menyebabkan peningkatan Kinerja Karyawan sebesar 0,460. 
4. Lingkungan kerja memiliki koefisien positif sebesar 493 artinya dengan adanya lingkungan pekerjaan sebesar itu alhasil mampu ditingkatkan satu satuan maka akan menyebabkan peningkatan performa Karyawan sebesar 0,460.

\section{Uji Hipotesis}

\section{Pengujian Hipotesis dengan jalur Parsial}

Dari analisis ini bisa dilihat melalui tabel 4.15 berikut :

Tabel 6 Pengujian terhadap Hipotesis

\begin{tabular}{|c|c|c|c|}
\hline Faktor Independen & t-hitung & t-tabel & Signifikan \\
\hline Stres Kerja & $-1,815$ & 2,005 & 0,081 \\
\hline Kepuasan Kerja & 4,078 & 2,005 & 0,000 \\
\hline Lingkungan Kerja & 4,387 & 2,005 & 0,000 \\
\hline
\end{tabular}

Dari tabel 6 diatas dapat dijelaskan yaitu sebagai berikut:

1. Peran Stres Kerja (X1) terhadap Kinerja seorang Karyawan(Y)

Dari tabel 6 diatas dapat dilihat bahwa t-hitung -1,815 dan t-tabel 2,055 dimana thitung lebih kecil dari t-tabel $(-1,815<2,055)$ atau tingkat signifikan lebih besar dari dari alpha $(0,081>0,05)$ maka dapat diperoleh $\mathrm{H}_{0}$ diterima Ha ditolak, hal ini dapat diartikan bahwa stres kerja memiliki koefisen negatif terhadap kinerja karyawan, sehingga dapat disimpulkan bahwa stres kerja tidak berperan terhadap kinerja karyawan.

2. Peran Kepuasan Kerja (X2) terhadap Kinerja Karyawan(Y)

Dari tabel 6 diatas dapat dilihat bahwa t-hitung 4,078 dan t-tabel 2,055 dimana thitung lebih kecil dari t-tabel $(4,078>2,055)$ atau tingkat signifikan lebih besar dari alpha $(0,000<0,05)$ maka dapat diperoleh $\mathrm{H}_{0}$ ditolak Ha diterima, hal ini dapat diartikan bahwa kepuasan kerja mempunyai peran positif terhadap kinerja karyawan.

3. Peran Lingkungan Kerja (X3) terhadap Kinerja Karyawan(Y)

Dari tabel diatas dapat dilihat bahwa t-hitung 4,387 dan t-tabel 2,055 dimana thitung lebih besar dari t-tabel $(4,387>2,055)$ atau tingkat signifikan lebih besar dari dari alpha $(0,000<0,05)$ maka dapat diperoleh $\mathrm{H}_{0}$ ditolak Ha diterima. hal ini dapat diartikan bahwa lingkungan kerja berperan positif terhadap kinerja karyawan

\section{Pengujian Hipotesis Secara Bersama-Sama (Uji-F)}

Berdasarkan pengujian $\mathrm{F}$ dapat dilihat bahwa

Tabel 7 Pengujian Hipotesis Secara Bersama-Sama (Uji F) ANOVA $^{\mathrm{a}}$

\begin{tabular}{|rl|r|r|r|r|r|}
\hline Model & & Sum of Squares & Df & Mean Square & F & Sig. \\
\hline \multirow{3}{*}{1} & Regression & 693,942 & 3 & 231,314 & 26,906 &, $000^{\mathrm{b}}$ \\
& Residual & 223,524 & 26 & 8,597 & & \\
& Total & 917,467 & 29 & & & \\
\hline
\end{tabular}

a. Varibel Y Kinerja.Karyawan

b. Varibel X Lingkungan.Kerja, Kepuasan.Kerja, Stres.Kerja 
Berdasarkan tabel tabel 7 terlihat bahwa nilai $\mathrm{F}_{\text {hitung }}$ dengan $\mathrm{F}_{\text {tabel }}$ karena nilai $\mathrm{F}$ hitung lebih besar dari nilai $\mathrm{F}_{\text {tabel }}(26,906$ > 2,98). Nilai F 8,359 dengan nilai signifikan 0,000 lebih kecil dari 5\%. Maka diperoleh $\mathrm{H}_{\mathrm{o}}$ ditolak dan $\mathrm{H}_{\mathrm{a}}$ diterima, yang berarti hal ini dilakukan secara bersama-sama antara Stres Kerja, Kepuasan Kerja dan Lingkungan Kerja mempunyai peran terhadap Kinerja Karyawan. Sedangkan lihat koefisien determinasi (

Tabel 8. Hasil Pengujian Besaran Determinasi

\begin{tabular}{|l|r|r|r|r|}
\hline Model & \multicolumn{1}{|c|}{$\mathrm{R}$} & R Square & \multicolumn{1}{|c|}{$\begin{array}{c}\text { Adjusted R } \\
\text { Square }\end{array}$} & $\begin{array}{l}\text { Std. Error of the } \\
\text { Estimate }\end{array}$ \\
\hline 1 &, $870^{\mathrm{a}}$ &, 756 &, 728 & 2,932 \\
\hline
\end{tabular}

Berdasarkan tabel 8 diatas diperoleh angka $\mathrm{R}^{2}$ (R Square) sebesar 0,728 hal ini dapat dilihat bahwa kontribusi variabel Stres Kerja, Kepuasan Kerja dan Lingkungan Kerja terhadap Kinerja Karyawan adalah 0,728 atau 72,8\% dengan sisa kontribusi 27,2\% yang dipengaruhi oleh variable lain.

\section{Pembahasan Hipotesis}

\section{Peran Stres Kerja (X1) terhadap Kinerja seorang Karyawan(Y)}

Berdasarkan pengujian secara parsial dapat dilihat bahwa t-hitung $-1,815$ dan $\mathrm{t}$ tabel 2,055 dimana t-hitung lebih kecil dari t-tabel $(-1,815<2,055)$ atau tingkat signifikan lebih besar dari dari alpha $(0,081>0,05)$ maka dapat diperoleh $\mathrm{H}_{0}$ diterima Ha ditolak, hal ini dapat diartikan bahwa stres kerja memiliki pengaruh negatif yang tidak signifikan terhadap kinerja karyawan. Teori yang ditemukan bahwa stres kerja berdampak negatif bagi kinerja karyawan yang dapat dilihat dari stres yang dialaminya. (Dharmayasa \& Adnyani, 2020) menyatakan bahwa stres kerja yang tinggi akan mengakibatkan kinerja karyawan maupun perusahaan menjadi kurang optimal. Stres kerja juga akan dapat menghamat karir seseorang dalam perusahaan. Stres kerja yang tinggi akan menyebabkan emosional seseorang menjadi tidak dapat dikontrol dengan baik sehingga menyebabkan suatu ketegangan dalam dirinya. Hasil penelitian tersebut dinyatakan sejalan dengan penelitian (Sandiartha \& Suwandana, 2020) bahwa stres kerja tidak memiliki pengaruh terhadap kinerja karyawan.

\section{Peran Kepuasan Kerja (X2) terhadap Kinerja Karyawan(Y)}

Berdasarkan pengujian secara parsial dapat dilihat bahwa bahwa t-hitung 4,078 dan t-tabel 2,055 dimana t-hitung lebih kecil dari t-tabel $(4,078>2,055)$ atau tingkat signifikan lebih besar dari alpha $(0,000<0,05)$ maka dapat diperoleh $\mathrm{H}_{0}$ ditolak Ha diterima, hal ini dapat diartikan bahwa kepuasan kerja memiliki pengaruh positif yang signifikan terhadap kinerja karyawan. Secara teori bahwa kepuasan kerja berdampak positif bagi kinerja karyawan diaman dengan adanya penghargaan yang diberikan kepada karyawan. Secara teori bahwa kepuasan kerja berdampak positif bagi kinerja karyawan diaman dengan adanya penghargaan yang diberikan kepada karyawan. Jika penghargaan yang diberikan seseuai dengan prestasi karyawan maka ia akan merasa puas terhadap apa yang diberikan oleh perusahaan begitupun sebaliknya karyawan yang tidak puas akan 
merasa frustasi dalam pekerjaannya. (Nuryanti, 2020) menyatakan bahwa semakin puasnya seseorang terhadap pekerjaannya akan menyakibatkan semakin tingginya kinerja seseorang tersebut., begitupun sebaliknya jika seseorang merasakan ketidakpuasan dalam pekerjaannya akan akan menyebabkan penurunan pada kinerjanya sehingga apa yang menjadi tujuan perusahaan tidak tercapai

Hasil penelitian tersebut dinyatakan sejalan dengan penelitian (Indrawati, 2017) bahwa terdapat kepuasan kerja memiliki pengaruh yang positif terhadap kinerja karyawan.

\section{Peran Lingkungan Kerja (X3) terhadap Kinerja Karyawan(Y)}

Berdasarkan pengujian secara parsial dapat dilihat bahwa t-hitung 4,387 dan ttabel 2,055 dimana t-hitung lebih besar dari t-tabel $(4,387>2,055)$ atau tingkat signifikan lebih besar dari dari alpha $(0,000<0,05)$ maka dapat diperoleh $\mathrm{H}_{0}$ ditolak Ha diterima. hal ini dapat diartikan bahwa lingkungan kerja memiliki pengaruh positif yang signifikan terhadap kinerja karyawan. Lingkungan kerja adalah suatu alat atau suasana yang dapat mempengaruhi kinerja karyawan, jika lingkungan kerja karyawan kondusif maka tentunyaakan dapat meningkatkan kinerja karyawan. Semakin baiknya lingkungan kerja pada suatu perusahaan maka akan mengakibatkan sekain tingginya kinerja karyawan hal ini disebabkan karena karyawan merasa nyaman dan aman pada lingkungannya. Lingkungan kerja yang nyaman merupakan lingkungan dimana pimpinan memberikan suasana yang baik, fasilitas yang baik dan lainnya sehingga akan dapat membawa dampak psitif bagi karyawan terhadap perusahaan (Yuliantari, 2020)

Hasil penelitian tersebut dinyatakan sejalan dengan penelitian (Rosowulan, 2020) bahwa bahwa terdapat lingkungan kerja memiliki pengaruh yang positif terhadap kinerja karyawan.

4. Peran Stres Kerja (X1), Kepuasan Kerja (X2) dan Lingkungan Kerja (X3) terhadap Kinerja Karyawan(Y)

Berdasarkan pengujian secara simultan dapat dilihat bahwa

nilai $\mathrm{F}_{\text {hitung }}$ dengan $\mathrm{F}_{\text {tabel }}$ karena nilai $\mathrm{F}_{\text {hitung }}$ lebih besar dari nilai $\mathrm{F}_{\text {tabel }}(26,906>$ 2,98). Nilai F 8,359 dengan tingkat signifikan 0,000 lebih kecil dari 5\%. Maka diperoleh $\mathrm{H}_{\mathrm{o}}$ ditolak dan $\mathrm{H}_{\mathrm{a}}$ diterima, yang berarti hal ini dilakukan secara bersamasama antara Stres Kerja, Kepuasan Kerja dan Lingkungan Kerja berpengaruh signifikan terhadap Kinerja Karyawan. Artinya bahwa untuk mendapat kinerja yang optimal perusahaan harus dapat memperhatikan tingkat stres kerja, kepuasan kerja dan lingkungan kerja karyawan.

\section{KESIMPULAN}

Beberapa simpulan menunjukkan bahwa: (a) bahwa stres kerja mempunyai peran negatif terhadap kinerja karyawan, (b) bahwa kepuasan kerja mempunyai peran positif terhadap kinerja karywan, (c) bahwa lingkungan kerja mempunyai peran positif terhadap kinerja karywan, (d) bahwa secara simultan bahwa stres kerja, kepuasan kerja dan lingkungan kerja berperan terhadap kinerja karyawan. Direkomendasikan peda peneliti 
selanjutnya untuk dapat mengembangakan hasil penelitian yang dilakukan dengan melibatkan variabel-variabel yang berkaitan dengan kinerja karyawan seperti motivasi, prestasi kerja, promosi jabatan dan lain sebagainya yang mempengaruhi kinerja karyawan. Sehingga didapatkan hasil penelitian yang kebih akurat untuk dapat meningkatkan kinerja karyawan.

\section{DAFTAR PUSTAKA}

Afandi. (2018). Manajemen Sumber Daya Manusia (Teori, Konsep dan Indikator). Zanafa Publishing.

Amri, A. (2020). Dari insecure menjadi bersyucure 27 kisah nyata dari kami yang hampir menyerah. Ladang Kata.

Amri, A., \& Ramdani, Z. (2021). Effect of organization commitment, work motivation , and work discipline on employee performance (case study: pt . pln (persero) p3b Sumatera upt Padang). International Journal of Educational Management and Innovation, 2(1), 88-99. https://doi.org/10.12928/ijemi.v2i1.3183

Arshadi, N., \& Damiri, H. (2013). The relationship of job stress with turnover intention and job performance: Moderating role of OBSE. Procedia - Social and Behavioral Sciences, 84(2003), 706-710. https://doi.org/10.1016/j.sbspro.2013.06.631

Arshadia, N. (2010). Basic need satisfaction, work motivation, and job performance in an industrial company in Iran. Procedia - Social and Behavioral Sciences, 5, 1267-1272. https://doi.org/10.1016/j.sbspro.2010.07.273

Changgriawan, G. S. (2017). Pengaruh kepuasan kerja dan motivasi kerja terhadap kinerja karyawan di One Way Production. Agora, 5(2).

Danang. (2015). Manajemen dan Pengembangan Sumber Daya Manusia. CAPS (Center for Academic Publishing Service).

Dharmayasa, P. B., \& Adnyani, I. G. A. D. (2020). Pengaruh Stres Kerja, Kepuasan Kerja Dan Kompensasi Finansial Terhadap Kinerja Karyawan. E-Jurnal Manajemen, 9(8), 2915-2935.

Indrawati. (2017). Pengaruh Self Esteem, Self Efficacy, dan Kepuasan Kerja Terhadap Kinerja Karyawan (Stud Kasus Perawat RS Siloam Manado). Jurnal Riset Bisnis Dan Manajemen, Vol. 2 No.

Indrawati, A. D. (2013). Pengaruh kepuasan kerja terhadap kinerja karyawan dan kepuasan pelanggan pada rumah sakit swasta di kota denpasar. Matrik: Jurnal Manajemen, Strategi Bisnis Dan Kewirausahaan.

Jauvani, E. (2013). Manajemen sumber daya manusia. Prenhalindo.

Julvia, C. (2016). Pengaruh stres kerja dan konflik kerja terhadap kinerja karyawan. Ilmiah Manajemen Bisnis.

Mahardiani, Y., \& Pradhanawati, A. (2013). Pengaruh stres kerja dan lingkungan kerja fisik terhadap kinerja karyawan outsourcing pada pt. Bank jateng cabang koordinator dan cabang pembantu wilayah kota semarang. Jurnal Administrasi Bisnis (JAB), 2(1).

Marchelia, V. (2014). Stres kerja ditinjau dari shift kerja pada karyawan. Jurnal Ilmiah Psikologi Terapan, 2(1), 130-143.

Monroe, C., Loresto, F., Horton-Deutsch, S., Kleiner, C., Eron, K., Varney, R., \& Grimm, 
S. (2020). The value of intentional self-care practices: The effects of mindfulness on improving job satisfaction, teamwork, and workplace environments. Archives of Psychiatric Nursing. https://doi.org/10.1016/j.apnu.2020.10.003

Nabawi, R. (2020). Pengaruh lingkungan kerja, kepuasan kerja dan beban kerja terhadap kinerja pegawai. Maneggio: Jurnal Ilmiah Magister Manajemen, 2(2), 170-183.

Nuryanti. (2020). Kepuasan Kerja Dan Komitmen Organisasi Berpengaruh Terhadap Kinerja Karyawan. E-Jurnal Manajemen, 9(3).

Prasetyo. (2019). Manajemen Sumber Daya Manusia. Rosdakarya.

Prawirosentono, S. (2014). Manajemen Sumber Daya Manusia "Kebijakan Kinerja Karyawan". BPFE.

Priansa. (2016). Manajemen SDM dalam Organisasi Publik dan Bisnis. Alfabeta.

Purwato. (2017). Manajemen Sumber Daya Manusia. Rajawali Pers.

Rahmawanti, N. P. (2014). Pengaruh lingkungan kerja terhadap kinerja karyawan (Studi pada karyawan kantor pelayanan pajak Pratama Malang Utara). Jurnal Administrasi Bisnis, 8(2).

Rivai. (2015). Manajemen Sumber Daya Manusia untuk Perusahaan (Edisi Ke 6). Raja Grafindo Persada.

Rosowulan. (2020). Pengaruh Lingkungan Kerja dan Kepuasan Kerja terhadap Kinerja Karyawan. BIOnatural, Volume 5 N(ISSN: 2355-3790).

Sandiartha, I. W. B., \& Suwandana, I. G. M. (2020). Pengaruh stres kerja terhadap kinerja karyawan dimediasi oleh kepuasan kerja karyawan koperasi graha canti semawangsanur. E-Jurnal Manajemen, 9(5), 1899-1920.

Saputra, A. T., Bagia, I. W., Yulianthini, N. N., \& SE, M. (2016). Pengaruh kepuasan kerja dan loyalitas karyawan terhadap kinerja karyawan. Jurnal Manajemen Indonesia, $4(1)$.

Sari, R., Muis, M., \& Hamid, N. (2012). Pengaruh kepemimpinan, motivasi, dan stres kerja terhadap kinerja karyawan pada bank syariah mandiri kantor cabang Makassar. Jurnal Analisis, 1(1), 87-93.

Sedarmayanti. (2017). Manajemen Sumber Daya Manusia. Refika Aditama.

Sugiyono. (2017). Metode penelitian kuantitatif, kualitatif, dan $R \& D$ (26th ed.). Alfabeta.

Suharsimi, A. (2010). Prosedur penelitian suatu pendekatan praktik. Rineka Cipta.

Viotti, S., Sottimano, I., Converso, D., \& Guidetti, G. (2020). The relationship between psychosocial characteristics of the work environment and job satisfaction in an Italian public ECE service: A cross-lagged study. Early Childhood Research Quarterly, 53, 464-475. https://doi.org/10.1016/j.ecresq.2020.06.002

Wang, Y., Huang, Q., Davison, R. M., \& Yang, F. (2020). Role stressors, job satisfaction, and employee creativity: The cross-level moderating role of social media use within teams. Information and Management, 103317. https://doi.org/10.1016/j.im.2020.103317

Wartono, T. (2017). Pengaruh stres kerja terhadap kinerja karyawan. Jurnal Ilmiah Prodi Manajemen Universitas Pamulang |, 4(2), 41-55.

Wibowo. (2017). Manajemen Kinerja (Edisi Ke 5). Raja Grafindo Persada.

Yozgat, U., Yurtkoru, S., \& Bilginoğlu, E. (2013). Job stress and job performance among 
employees in public sector in istanbul: Examining the moderating role of emotional intelligence. Procedia - Social and Behavioral Sciences, 75, 518-524. https://doi.org/10.1016/j.sbspro.2013.04.056

Yuliantari, K., \& Prasasti, I. (2020). Pengaruh Lingkungan Kerja Terhadap Kinerja Karyawan Pada LLDIKTI Wilayah III Jakarta. Widya Cipta: Jurnal Sekretari Dan Manajemen, 4(1), 76-82. https://doi.org/10.31294/widyacipta.v4i1.7699 